żynie Krakowsko-Częstochowskiej (2005), R. Faracik, Turystyka $w$ strefie podmiejskiej Krakowa (2006) oraz podręcznik pt. Turystyka (2007), pod red. W. Kurka, ujmujący kompleksowo zagadnienia turystyczne.

Współczesna problematyka badawcza pracowników Zakładu koncentruje się m.in. na przemianach $\mathrm{w}$ zagospodarowaniu i ruchu turystycznym w Polsce wynikających z transformacji społeczno-ekonomicznej kraju, na społecznych, ekonomicznych i przyrodniczych skutkach rozwoju turystyki, na funkcji turystycznej obszarów chronionych, na przemianach funkcji leczniczej i wypoczynkowej uzdrowisk, na turystyce kulturowej w miastach historycznych, a zwłaszcza w Krakowie, na możliwościach aktywizacji ekonomicznej terenów wiejskich poprzez rozwój turystyki oraz na roli samorządów lokalnych $w$ aktywizacji turystycznej regionów i miejscowości w południowej Polsce.

Zakład Gospodarki Turystycznej i Uzdrowiskowej Instytutu Geografii i Gospodarki Przestrzennej UJ zajmuje się także działalnością dydaktyczną zarówno na studiach dziennych, jak i zaocznych. Aktualnie na kierunku geografia w zakresie turystyki specjalizuje się około 400 studentów.

Wtodzimierz Kurek

\section{Geografia turyzmu w Uniwersytecie Jagiellońskim Zakład Geografii Religii}

Problematyka związana $\mathrm{z}$ geografią religii pojawiła się w Krakowie w połowie XIX w. Zajmował się nią przede wszystkim Wincenty Pol, kierownik pierwszej na ziemiach polskich Katedry Geografii, utworzonej w 1849 r. w Uniwersytecie Jagiellońskim. Później badania z tej dziedziny podejmowano w okresie międzywojennym, zwłaszcza przez Studium Turyzmu UJ, które działało w latach 1936-1939 przy Instytucie Geografii, a kierowane było przez Stanisława Leszczyckiego. W latach 80 . XX w. omawiana problematyka zaczęła ponownie stanowić przedmiot zainteresowań geografów krakowskich. W czerwcu 1994 r. w Instytucie Geografii Uniwersytetu Jagiellońskiego utworzono Zakład Geografii Religii (jedyny tego skich Europy (Tourism in European mountainous areas) (2004); M. Mika, Turystyka a przemiany środowiska przyrodniczego Beskidu Slaskiego (Tourism and environmental transformations in Silesian Beskids) (2004); R. Pawlusiński, Samorzad lokalny a rozwój turystyki na Wyżynie Krakousko-Czestochowskiej (Local authorities and tourism development in the region of Krakowsko-Czestochouska Upland) (2005); R. Faracik, Turystyka $w$ strefie podmiejskiej Krakowa (Tourism in the suburban areas of Kraków) (2006) and the handbook Turystyka (Tourism) (2007), ed. W. Kurek, in which tourism issues are formulated in a complexway.

The present research subjects of departmental members include: changes in tourism development and tourism activity in Poland resulting from its socio-economic transformation; the social, economic and environmental effects of tourism development; the tourism function of protected areas; changes in the medical and recreational function of health resorts; cultural tourism in historical cities, especially in Kraków; opportunities for the 'economic activation' of rural areas by tourism development, and the role played by local government in encouraging tourism in regions and individual locations in southern Poland.

The Department of Tourism and Health Resort Management at the Institute of Geography and Spatial Management also runs educational activities both for regular and extramural students. At present, there are nearly 400 students of geography specializing in tourism.

Włodzimierz Kurek

\section{Geography of tourism at the Jagiellonian University Department of Geography of Religion}

Issues of the geography of religion became of interest for Krakow scholars in the mid-19th $\mathrm{c}$. Interest in the subject was pursued chiefly by Wincenty Pol, the Director of the first Department of Geography in Poland which was established at the Jagiellonian University in 1849. Later on, research in this area was undertaken in the interwar period, especially in the Tourism Studium (Studium Turyzmu) which operated at the Institute of Geography of the Jagiellonian University in 1936-1939 under Stanisław Leszczycki. In the 1980s these issues were resumed by Kraków geographers. In June 1994, the Department of Geography of Religion was established at the Jagiellonian University as the only such institution in Poland on the initiative of Prof. Antoni Jackowski 
rodzaju w Polsce), którego twórcą i kierownikiem (do 2005) był prof. Antoni Jackowski. Obecnie Zakładem kierują dr hab. Michał Paszkowski i dr Izabela Sołjan.

Izabela Soljan, dr (e-mail: i.soljan@geo.uj.edu. pl). Specjalność: geografia religii, geografia turyzmu. Zainteresowania badawcze: geografia religii; turystyka religijna; relacje środowisko-człowiekreligia, ze szczególnym uwzględnieniem migracji pielgrzymkowych; geografia religii Europy; geografia biblijna; przemiany krajobrazu sakralnego w Polsce.

Elżbieta Bilska-Wodecka, dr (e-mail: e.bilska@) geo.uj.edu.pl). Specjalność: geografia religii, geografia spoleczno-ekonomiczna. Zainteresowania badawcze: geografia religii, ze szczególnym uwzględnieniem migracji pielgrzymkowych; geneza, funkcjonowanie i typologia kalwaryjskich ośrodków kultu religijnego; rozmieszczenie religii na świecie.

Antoni Jackowski (e-mail: a.jackowski@geo.uj. edu.pl), prof. honorowy UJ, m.in. członek korespondent Papieskiej Międzynarodowej Akademii Maryjnej (Pontificia Academia Mariana Internationalis) w Rzymie, Society of Pilgrimages Studies (Allahabad, Indie). Specjalność: geografia religii, geografia turyzmu. Zainteresowania badawcze: geografia religii; turystyka religijna; geografia kultury, historia geografii i turystyki.

Od 1995 r. Zakład wydaje czasopismo naukowe „Peregrinus Cracoviensis”, jedyne tego typu w Europie. Pracownicy Zakładu opublikowali blisko 15 książek dotyczących badanej problematyki, m.in. podręczniki akademickie. Zakład Geografii Religii był organizatorem lub współorganizatorem wielu naukowych konferencji i seminariów.

\section{Antoni Jackowski}

\section{Geografia turyzmu w Uniwersytecie Wrocławskim Zakład Geografii Regionalnej i Turystyki}

Zainteresowanie problematyką geografii turyzmu w Instytucie Geografii i Rozwoju Regionalnego Uniwersytetu Wrocławskiego sięga pierwszych lat powojennych i wiąże się wówczas z pracami W. Walczaka, kierownika Zakładu Geografii Regionalnej. Należą do nich m.in. monografie - Ziemia Klodzka $(1951,1956)$ i Karkonosze (z T. Steciem, 1954), Turystyczna mapa Karkonoszy (1947) i Zarys geografii turystycznej Polski (1963). (its director until 2005). Currently the department is directed by Dr Michal Paszkowski (Doctor habilitatus) and Dr Izabela Sołjan.

Izabela Sołjan, PhD (e-mail: i.soljan@geo.uj. edu.pl). Specialisms: geography of religion and geography of tourism. Research interests: geography of religion, religious tourism, environment-man-religion' relations with emphasis on pilgrimages, the geography of religion in Europe, biblical geography, changes in Poland's sacred landscape.

Elżbieta Bilska-Wodecka, PhD (e-mail: e.bilska @geo.uj.edu.pl). Specialisms: geography of religion, socio-economic geography. Research interests: geography of religion with emphasis on pilgrimages; the origins, functioning and typology of centres of religious worship of the Calvary type; the distribution of religions in the world.

Antoni Jackowski (e-mail: a.jackowski @geo. uj.edu.pl), Honorary Professor at the Jagiellonian University and corresponding member of the Pontifical International Marian Academy (Pontificia Academia Mariana Internationalis) in Rome and the Society of Pilgrimage Studies (Allahabad, India). Specialies: geography of religion, geography of tourism. Research interests: geography of religion, religious tourism, geography of culture, history of geography and tourism.

Since 1995 the department has published Peregrinus Cracoviensis, the only research journal of this type in Europe. The staff of the department have produced nearly 15 publications in book form on the subject, including academic textbooks. The Department of Geography of Religion has organised or co-organised many conferences and seminars.

Antoni Jackowski
Interest in the problems of tourism geography in the Institute of Geography and Regional Development at the University of Wrocław dates back to the early post-war period and refers mostly to the work of W. Walczak, the head of the Regional Geography Department. The work includes monographs, The Ktodzko Region $(1951,1956)$, and The Karkonosze Mountains (with T. Steć, 1954), a Tourist map of the Karkonosze (1947), and an Outline of the Tourist Geography of Poland (1963). 